\title{
SYSTEM MIĘDZYNARODOWY JAKO KATEGORIA W NAUCE O STOSUNKACH MIĘDZYNARODOWYCH
}

\author{
Dariusz Kondrakiewicz \\ Zakład Stosunków Międzynarodowych, \\ Wydział Politologii UMCS, \\ Plac Litewski 3, 20-080 Lublin \\ email: dariusz.kondrakiewicz@poczta.umcs.lublin.pl
}

\begin{abstract}
Streszczenie: Celem artykułu jest analiza kategorii systemu międzynarodowego w nauce o stosunkach międzynarodowych. Autor omawia pojęcie systemu, następnie różnorodne definicje systemu międzynarodowego, jego główne części, klasyfikację systemów międzynarodowych oraz kategorię systemu międzynarodowego w ujęciu głównych paradygmatów teorii stosunków międzynarodowych: behawioralnego, realistycznego, liberalnego i konstruktywistycznego. Generalną konkluzją autora jest stwierdzenie, że system międzynarodowy wciąż pozostaje kluczową kategorią w nauce o stosunkach międzynarodowych.
\end{abstract}

Słowa kluczowe: system międzynarodowy, stosunki międzynarodowe, teoria stosunków międzynarodowych

\section{POJĘCIE SYSTEMU}

Słowo system pochodzi z języka greckiego od systēmatikós - zestawiony lub sýstèma - zestawienie i zwykle oznacza całościowy i uporządkowany układ, zbiór zasad, twierdzeń lub reguł postępowania. ${ }^{1}$ Słowniki i encyklopedie podają różne sposoby rozumienia tego pojęcia, które najczęściej występuje w następujących znaczeniach jako: uporządkowany zespół idei lub teorii; szczególny sposób działania bądź metoda wykonywania złożonych czynności; rodzaj infrastruktury, grupy maszyn, urządzeń czy rzeczy, części lub ich wyposażenie, pozostających ze sobą w regularnych relacjach; żywy organizm lub te jego części, w których jego funkcje są wykonywane przez naturalne procesy i właściwe organy; grupa

1 W. Kopaliński, Stownik wyrazów obcych i zwrotów obcojęzycznych, Warszawa 1983, s. 410. 
ciał niebieskich poruszających się po orbitach wokół centralnego obiektu; reguły i metody klasyfikacji jednostek miar i walut; sposoby podziału okresów historycznych; formy ustroju państwa. ${ }^{2}$

Systemem może być również uporządkowany układ elementów lub jednostek, które tworzą pewną całość i służą określonemu celowi; ogół przepisów i zasad obowiązujących w danej dziedzinie lub zasady jej organizacji; określony sposób wykonywania jakiejś czynności; bądź też spójny zbiór poglądów, tez i hipotez tworzących jakąś teorię. ${ }^{3}$

System jest pojęciem powszechnie stosowanym we wszystkich dziedzinach nauki, zarówno teoretycznych jak i empirycznych, w tym zwłaszcza w naukach przyrodniczo-fizycznych i społecznych, przyjmując jednak nieco odrębne znaczenie i egzemplifikacje. ${ }^{4}$

Powszechnie uznaje się, że twórcą ogólnej teorii systemów był wybitny przedstawiciel nauk biologicznych L. von Bertalanffy. Jego koncepcje zyskały na tyle szeroki rozgłos w środowisku naukowym, że wkrótce znalazły wielu zwolenników i kontynuatorów, którzy twórczo zmienili jego założenia i przystosowali je do specyfiki w innych dziedzinach, stając się prekursorami nowych nurtów badawczych. Byli to N. Wiener w cybernetyce i C. Shannon w teorii informacji, a po opublikowaniu wyników ich prac model cybernetyczny został szybko upowszechniony i zastosowany w naukach społecznych: przez T. Parsonsa - w socjologii, J. Piageta - w psychologii, K. Bouldinga - w ekonomii oraz przez D. Eastona i G. Almonda - w naukach prawnych i politycznych. ${ }^{5}$

Większość autorów posługuje się bardzo ogólną definicją systemu. L. von Bertalanffy sądzi, że system ,można zdefiniować jako zbiór elementów pozostających we wzajemnych relacjach”. ${ }^{6}$ M. Mazur zakłada, że system to „zbiór elementów i zachodzących między nimi relacji". ${ }^{7}$ R. Kulikowski proponuje stosowanie

2 The New Lexicon Webster's Encyclopedic Dictionary of the English Language, Canadian Edition, New York 1988, s. 1004; Oxford Advanced Learner's Dictionary of Current English, A. S Hornby, ed. by S. Wehmeier, Oxford 2000, s. 1320; Le petit Robert 1. Dictionnaire alphabétique et analogique de la langue française, Paris 1990, s. 1909; Nowa encyklopedia powszechna PWN, t. 6, Warszawa 1997, s. 152-153; Leksykon PWN, Warszawa 2004, s. 1050-1051; Nowa encyklopedia powszechna PWN, t. 8, Warszawa 2004, s. 44; Stownik wyrazów obcych PWN, oprac. L Wiśniakowska, Warszawa 2004, s. 963; Wielka encyklopedia PWN, t. 26, Warszawa 2005, s. 337.

3 Stownik języka polskiego, t. 3, R-Z, Warszawa 1981, s. 387; Popularny słownik języka polskiego, red. B. Dunaj, Warszawa 1999, s. 681; Podręczny słownik języka polskiego, oprac. E. Sobol, Warszawa 1999, s. 981; Nowy stownik języka polskiego PWN, Warszawa 2002, s. 980; Uniwersalny stownik języka polskiego, pod red. S. Dubisza, Warszawa 2003, s. 619-620.

4 L. von Bertalanffy, Ogólna teoria systemów, Podstawy. Rozwój. Zastosowania, przekł. E. Woydyłło-Woźniak, Warszawa 1984, s. 37-38.

5 J. E. Dougherty, R. L. Pfaltzgraff, Jr., Contending Theories of International Relations. A Compresive Survey, $2^{\text {nd }}$ edition, New York 1981, s. 139-146; J. Kukułka, Problemy teorii stosunków międzynarodowych, Warszawa 1978, s. 160-162; Z. J. Pietraś, Podstawy teorii stosunków międzynarodowych, Lublin 1986, s. 114.

${ }^{6}$ L. von Bertalanffy, Ogólna, op. cit., s. 86.

7 M. Mazur, Cybernetyka i charakter, Warszawa 1999, s. 45. 
pojęcia systemu jako ,zespołu elementów lub obiektów, które są zespolone lub powiązane w całość przez określone związki lub zależności". ${ }^{8}$ P. Sienkiewicz określa, że systemem można nazywać „każdy obiekt wyróżniony z badanej rzeczywistości, stanowiący całość tworzoną przez zbiór obiektów elementarnych (elementów) i powiązań relacji między nimi". ${ }^{9}$ B. Krauz-Mozer i W. Szostak zakładają, że „kategoria system oznacza zbiór obiektów powiązanych ze sobą przynajmniej jedną relacją". ${ }^{10} \mathrm{~W}$ opinii A. Bodnara, „system jest zbiorem elementów i relacji między nimi". ${ }^{11}$ A. Chodubski przez system rozumie ,uporządkowany wewnętrznie w całość układ elementów mający określoną strukturę". ${ }^{12}$ Według J. Kukułki, system stanowi „całość elementów, między którymi istnieje określona struktura sprzężeń". ${ }^{13}$ Zdaniem Z. J. Pietrasia, system składa się „Z rozróżnialnych elementów powiązanych w strukturę i oddzielonych granicą od środowiska" ${ }^{14} \mathrm{~K}$. N. Waltz podaje zwięzłą definicję systemu jako „zbiór interaktywnych elementów”. ${ }^{15}$ B. Buzan i R. Little twierdzą, że system to „układ złożony z ustrukturyzowanego zbioru oddziaływających na siebie jednostek". ${ }^{16}$ M. Simai przyjmuje, że system to „całość interakcji i współzależności między grupami lub podmiotami z wewnętrznym specyficznym układem lub strukturą". ${ }^{17}$ J. S. Nye uważa, że pojęcie systemu generalnie „odnosi się do zbioru powiązanych ze sobą elementów”, ale jego istotą jest to, że jest on zdecydowanie czymś więcej niż tylko prostą sumą tych elementów. ${ }^{18} \mathrm{~K}$. Mingst określa system jako „układ jednostek, obiektów lub części połączonych jaką̧s formą regularnych relacji”. ${ }^{19}$ R. Gilpin twierdzi, że system jest agregacją różnych bytów złączonych przez regularne interakcje według określonej formy jego kontroli. ${ }^{20} \mathrm{~W}$. Lamentowicz zakłada, że system to „układ złożony z części uporządkowanych w określony

${ }^{8}$ R. Kulikowski, Sterowanie w wielkich systemach, Warszawa 1970, s. 9.

${ }^{9}$ P. Sienkiewicz, Systemy kierowania, Warszawa 1989, s. 15.

${ }^{10}$ B.Krauz-Mozer, W. Szostak, Teoria polityki. Podstawy metodologiczne politologii empirycznej, Kraków 1993, s. 76.

${ }^{11}$ A. Bodnar, Historyczne uwarunkowania działań politycznych; system polityczny a podtoże historyczne, [w:] Elementy teorii polityki, pod red. K. Opałka, Warszawa 1989, s. 252.

${ }^{12}$ A. Chodubski, Wstęp do badań politologicznych, Gdańsk 1995, s. 75.

${ }^{13}$ J. Kukułka, Problemy, op. cit., s. 162.

${ }^{14}$ Z. J. Pietraś, Decydowanie polityczne, Warszawa-Kraków 1998, s. 57.

${ }^{15}$ K. N. Waltz, Theory of International Politics, Long Grove 2010, s. 40.

${ }^{16}$ B. Buzan, R. Little, Systemy międzynarodowe w historii świata, tłum. E. Brzozowska, Warszawa 2011, s. 555.

${ }^{17}$ M. Simai, The Future of Global Governance. Managing Risk and Change in the International System, Washington 2005, s. xvi.

${ }^{18} \mathrm{~J}$. S. Nye, Jr, Konflikty międzynarodowe. Wprowadzenie do teorii i historii, thum. M. Madej, Warszawa 2009, s. 63.

${ }^{19}$ K. Mingst, Podstawy stosunków międzynarodowych, przekł. G. Łuczkiewicz, M. Kabura, Warszawa 2006, s. 85.

${ }^{20}$ R. Gilpin, War and Change in World Politics, Cambridge 1981, s. 26. 
sposób według reguł wyznaczających ich wzajemne relacje". ${ }^{21} \mathrm{P}$. I. Wallerstein przyjmuje, że system „oznacza pewną całość powiązanych ze sobą elementów, posiadającą wewnętrzne reguły funkcjonowania oraz pewien rodzaj ciągłości". ${ }^{22}$ Natomiast $w$ ujęciu L. Löfgrena termin system jest synonimem porządku. ${ }^{23}$

Bardziej rozbudowaną definicję systemu proponuje R. Ackoff, którego zdaniem system jest zbiorem przynajmniej dwóch lub więcej elementów spełniających trzy określone warunki: 1) działanie każdego z elementów wpływa na działanie całości systemu; 2) działanie elementów oraz ich wpływ na całość są współzależne; 3) wszystkie podsystemy wpływają na działanie całości systemu, ale żaden $\mathrm{z}$ nich nie oddziałuje niezależnie. ${ }^{24}$

K. E. Boulding, kierując się wzrastającym poziomem złożoności, wyodrębnia następujące systemy: mechaniczne, homeostatyczne, biologiczne, odpowiadające wyższym gatunkom zwierząt, oraz ludzkie. ${ }^{25}$

Biorąc pod uwagę przedstawioną powyżej klasyfikację, można przyjąć za Z. J. Pietrasiem, że istnieją trzy zasadnicze rodzaje systemów: przyrodnicze, techniczne i społeczne. Każdy rodzaj systemów posiada własne, odrębne i specyficzne cechy. Spośród systemów społecznych możemy wyróżnić między innymi systemy ekonomiczne, prawne, kulturowe oraz polityczne. Wśród tych ostatnich możemy wyodrębnić grupę systemów międzynarodowych. ${ }^{26}$

\section{DEFINICJE SYSTEMU MIĘDZYNARODOWEGO}

Zagadnienia dotyczące teoretycznych i metodologicznych możliwości zastosowania ogólnej teorii systemów znalazły swoje odzwierciedlenie także w nauce o stosunkach międzynarodowych. I chociaż istnieje wiele definicji stworzonych przez różnych autorów, to nie udało się jak dotąd wypracować jednej, powszechnie akceptowanej i obowiązującej definicji systemu międzynarodowego. ${ }^{27}$

${ }^{21}$ W. Lamentowicz, Funkcje systemu politycznego a żywiołowa dynamika „,makrostruktur” życia społecznego, [w:] Z zagadnień teorii polityki, pod red. K. Opałka, Warszawa 1978, s. 89.

${ }^{22}$ I. Wallerstein, Analiza systemów - światów. Wprowadzenie, przekł. K. Gawlicz, M. Stanowski, Warszawa 2007, s. 143.

${ }^{23}$ L. Löfgren, Względne objaśnianie systemów, [w:] Ogólna, op. cit., s. 328.

${ }^{24}$ P. Sienkiewicz, 10 wykładów, Warszawa 2005, s. 24.

${ }^{25}$ K. E. Boulding, The Image: Knowledge in Life nad Society, Ann Arbor 1956, s. 8.

${ }^{26}$ Z. J. Pietraś, Podstawy, op. cit., s. 114.

${ }^{27}$ J. E. Dougherty, R. L. Pfaltzgraff, Jr., Contending Theories of International Relations. A Compresive Survey, $4^{\text {th }}$ edition, New York 1996, s. 100; T. Łoś-Nowak, Stosunki międzynarodowe. Teorie - systemy - uczestnicy, Wrocław 2000, s. 95; L. Zyblikiewicz, Struktura i ewolucja systemu międzynarodowego, [w:] E. Cziomer, L. W. Zyblikiewicz, Zarys wspótczesnych stosunków międzynarodowych, Warszawa 2006, s. 108-109; R. Tenerowicz, System międzynarodowy w teorii stosunków międzynarodowych, „Stosunki Międzynarodowe - International Relations” 2013, nr 2, s. 27; J. Kukułka, Problemy, op. cit., s. 168; Z. J. Pietraś, Podstawy, op. cit., s. 115-116. 
Niezwykle zwięzłą definicję systemu międzynarodowego przedstawia D. Messner, którego zdaniem są to „wzajemne relacje i oddziaływania między państwami" ${ }^{28}$

R. Aron mianem systemu określa „całość, utworzoną przez jednostki polityczne, które utrzymują ze sobą wzajemne regularne stosunki i z których każda może zostać wciągnięta w powszechną wojnę". ${ }^{29}$

R. Jackson i G. Sørensen zakładają, że system międzynarodowy w ujęciu historycznym można zasadniczo sprowadzić do systemu państw, którego podstawę tworzą ,stosunki łączące politycznie zorganizowane zbiorowości ludzkie, zajmujące odrębne terytoria, niepodlegające żadnej wyższej władzy ani sile oraz szczycące się pewną dozą niezależności od siebie nawzajem". ${ }^{30}$

P. Kennedy przyjmuje, że system międzynarodowy jest określany przez układ sił między wielkimi mocarstwami, który jest pochodną ich potencjału ekonomicznego, zastosowanych innowacji i rezultatem prowadzonych wojen. ${ }^{31}$

H. J. Morgenthau posługuje się pojęciem systemu międzynarodowego w odniesieniu do równowagi siły, „tak jak gdyby był to jeden system składający się ze wszystkich państw aktywnie zaangażowanych w politykę międzynarodową", chociaż często okazuje się, że „składa się on z pewnej liczby podsystemów, powiązanych wzajemnie, ale utrzymujących w swym obrębie własną równowagę siły". ${ }^{32}$

W opinii A. D. Rotfelda, ,system międzynarodowy jest to określony dynamiczny układ stosunków międzypaństwowych, który chroni - w formie traktatów lub porozumień politycznych - zespół wartości i interesy uznane przez jego twórców oraz określa reguły postępowania w ich wzajemnych stosunkach i mechanizmy samoregulacji umożliwiające utrzymanie, rozwój i dostosowywanie się systemu do zmieniających się uwarunkowań". ${ }^{33}$

J. S. Nye twierdzi, że międzynarodowy system polityczny „,stanowi wzorzec powiązań między państwami, chociaż nie składa się wyłącznie z państw”, ponieważ obejmuje także trudną do uchwycenia rolę, jaką odgrywają światowe media i opinia publiczna oraz przyjęte zasady działania. ${ }^{34}$

S. Hoffman przyjmuje, że system międzynarodowy to układ stosunków pomiędzy podstawowymi jednostkami polityki światowej, wyróżniający się zakre-

${ }^{28}$ D. Messner, World Society - Structures and Trends, [w:] Global Trends and Global Governance, ed. by P. Kennedy, D. Messner, F. Nuscheler, London 2002, s. 27.

${ }^{29}$ R. Aron, Pokoj i wojna między narodami,(teoria), thum. A. Mielczarek, Warszawa 1995, s. 127.

${ }^{30}$ R. Jackson, G. Sørensen, Wprowadzenie do stosunków międzynarodowych. Teorie i kierunki badawcze, tłum. A. Czwojdrak, Kraków 2006, s. 3.

${ }^{31}$ P. Kennedy, Mocarstwa świata. Narodziny. Rozkwit. Upadek. Przemiany gospodarcze $i$ konflikty zbrojne w latach 1500-2000, przeł. M. Kluźniak, Warszawa 1995, s. 8-12.

${ }^{32}$ H. J. Morgenthau, Polityka między narodami. Walka o potęgę i pokój, przejrzał i uzupełnił K. W. Thompson, wyd. skrócone, przeł. R. Włoch, Warszawa 2010, s. 215.

${ }_{33}$ A. D. Rotfeld, Europejski system bezpieczeństwa in statu nascendi, Warszawa 1990, s. 27.

${ }^{34}$ J. S. Nye, Jr., Konflikty, op. cit., s. 63. 
sem celów, do jakich dążą te jednostki, oraz zakresem zadań i środków do ich osiągnięcia. ${ }^{35}$

I. Clarke uważa, iż system międzynarodowy to ,uporządkowane zasady interakcji państw", przy czym część z tych podstawowych zasad, jak np. suwerenność i nieingerencja, podlega znaczącym przekształceniom, stanowiąc jeden z czynników złożoności współczesnych stosunków międzynarodowych. ${ }^{36}$

H. Bull zakłada, że ,system państw (lub system międzynarodowy) powstaje, kiedy dwa lub więcej państw utrzymuje między sobą wystarczające kontakty i posiada wystarczający wpływ na wzajemne decyzje, aby postępować - przynajmniej w pewnym zakresie - jako części całości”. ${ }^{37}$

G. Modelski określa system międzynarodowy jako system społeczny, spełniający określone wymagania strukturalne i funkcjonalne. Jego zdaniem, systemy międzynarodowe składają się ze zbioru obiektów, razem ze stosunkami między tymi obiektami i między ich atrybutami. Systemy międzynarodowe zawierają wzorce działania i oddziaływania między zbiorowościami i między jednostkami funkcjonującymi w ich imieniu. ${ }^{38}$

B. Buzan i R. Little zauważają, że w uproszczeniu system międzynarodowy stanowi „układ aktorów i ich wzajemnych oddziaływań stanowiących przedmiot stosunków międzynarodowych". ${ }^{39}$

Według J. Stefanowicza, przez system międzynarodowy należy rozumieć „zespół układów i zależności o fundamentalnym znaczeniu dla funkcjonowania mechanizmów, rządzących sceną międzynarodową". ${ }^{40}$

P. Sztompka definuje system światowy jako „ogarnięcie bezpośrednimi lub pośrednimi wpływami rynku kapitalistycznego wszystkich obszarów świata”. ${ }^{41}$

Zdaniem G. Aseniero, system światowy ,jest wynikiem procesów interakcji między państwami, kompleksem relacji między nimi”, w których rządzące elity narodowe starają się utrzymać owe kraje w międzynarodowym podziale pracy, regulować wewnętrzne procesy gospodarcze według norm wypracowanych przez system światowy oraz stwarzać przyjazny klimat dla inwestycji zagranicznych. ${ }^{42}$

E. Stadtmüller określa, że świat w XXI wieku staje się skomplikowanym systemem „powiązań między różnymi regionami, społeczeństwami, organizacja-

${ }^{35}$ S. Hoffmann, The State of War: Essays on the Theory and Practice of International Politics, New York 1965, s. 90.

${ }^{36}$ I. Clark, Globalizacja i ład pozimnowojenny, [w:] Globalizacja polityki światowej. Wprowadzenie do stosunków międzynarodowych, red. J. Baylis, S. Smith, Kraków 2008, s. 903-905.

${ }^{37}$ H. Bull, The Anarchical Society. A Study of Order in World Politics, London 1977, s. 9.

${ }^{38}$ J. E. Dougherty, R. L. Pfaltzgraff, Jr., Contending, op. cit., $2^{\text {nd }}$ edition, s. 147.

${ }^{39}$ B. Buzan, R. Little, Systemy, op. cit., s. 20.

${ }^{40}$ J. Stefanowicz, Anatomia polityki międzynarodowej, Torun 2001, s. 125.

${ }^{41}$ P. Sztompka, Socjologia. Analiza spoleczeństwa, Warszawa 2007, s. 599.

${ }^{42}$ G. Aseniero, Filozofia systemu światowego, [w:] U podłoża globalnych zagrożeń. Dylematy rozwoju, pod red. J. Daneckiego i M. Daneckiej, Warszawa 2003, s. 26-27. 
mi, ruchami, broniącymi różnych interesów na drodze rywalizacji, choć i współdziałania". ${ }^{43}$

Zdaniem B. Balcerowicza, system światowy to „sieć powiązanych ze sobą uczestników międzynarodowych, charakteryzujących się wysokim stopniem złożoności i hierarchicznego zróżnicowania". ${ }^{44}$

Podobnie uważa A. Rothert, przyjmując, że międzynarodowy system polityczny stanowią sieci powiązań pionowych i poziomych różnych „instytucji politycznych, spełniających funkcje rządzenia i wchodzących w relacje na różnych poziomach, państwowym, regionalnym i ponadnarodowym". ${ }^{45}$

A. Touraine przyjmuje, że „system polityczny jest siecią aktorów ograniczaną i przymuszaną przez pole działania historycznego, przez stan stosunków klasowych i przez wymogi integracji różnorodnych elementów w tej samej wspólnocie politycznej". ${ }^{46}$

M. Castells dowodzi, że rozwój nowoczesnych technologii informacyjnych w ostatnich dwóch dekadach doprowadził do powstania nowej struktury społecznej, przekraczającej granice państw narodowych, w której „,społeczeństwo sieci ukonstytuowało się jako system globalny, zapoczątkowując nową formę globalizacji charakterystyczną dla naszych czasów”, chociaż, jak podkreśla, „sieci globalne objęły niektórych ludzi i niektóre terytoria, wykluczając innych, przez co stworzyły geografię nierówności społecznych, ekonomicznych i technologicznych". ${ }^{47}$

I. Wallerstein w swoich pracach stosuje pojęcie system - świat, tworzący swoistą matrycę, składającą się ,z wielu instytucji, państw i systemu międzypaństwowego, przedsiębiorstw produkcyjnych, gospodarstw domowych, klas społecznych i różnego rodzaju grup tożsamościowych". ${ }^{48}$

A. M. Slaughter uważa, że odmienność powstającego nowego ładu światowego polega na łączeniu się państw oraz aktorów pozapaństwowych w skomplikowany model relacji zarówno wertykalnych, jak i horyzontalnych, tworząc rozległe i wielowymiarowe sieci. ${ }^{49}$

P. Frankowski stwierdza, że stosunki międzynarodowe wyróżnia kontrolowana niestabilność między dodatnimi a ujemnymi sprzężeniami zwrotnymi, gdyż „system stosunków międzynarodowych wykazuje bowiem wszystkie cechy systemu chaotycznego". ${ }^{50}$

${ }^{43}$ E. Stadtmüller, Międzynarodowy ład polityczny, [w:] Z. Cesarz, E. Stadtmüller, Problemy polityczne wspótczesnego świata, Wrocław 1996, s. 35.

${ }^{44}$ B. Balcerowicz, Pokój i ,nie-pokój” na progu XXI wieku, Warszawa 2002, s. 120.

${ }^{45}$ A. Rothert, Między porzadkiem a chaosem, Warszawa 2006, s. 14.

${ }^{46}$ A. Touraine, Samotworzenie się spoleczeństwa, przeł. A. Karpowicz, Kraków 2010, s. 215.

${ }^{47}$ M. Castells, Społeczeństwo sieci, przekł. M. Marody, K. Pawluś, J. Skawiński, S. Szymański, Warszawa 2010, s. 10.

${ }^{48}$ I. Wallerstein, Analiza, op. cit., s. 143.

49 A. M. Slaughter, A New World Order, Princeton 2004, s. 145.

${ }^{50}$ P. Frankowski, Stosunki międzynarodowe jako system chaotyczny, „Annales Universitatis Mariae Curie-Skłodowska", Sectio K, Politologia, vol. IX, 2002, s. 28-30. 
Jak wynika z przedstawionych powyżej definicji systemu międzynarodowego, można wskazać jego ewolucję jego pojmowania od systemu państwowego w kierunku systemu obejmującego także innych najważniejszych pozapaństwowych aktorów stosunków międzynarodowych.

Należy zatem przyjąć, że system międzynarodowy jest skomplikowaną siecią powiązań i relacji między uczestnikami stosunków międzynarodowych, charakteryzującą się rosnącym poziomem złożoności, wzajemnych zależności i hierarchicznego zróżnicowania.

\section{GLÓWNE CZĘŚCI SYSTEMU}

W ogólnym ujęciu w każdym systemie, w tym również w systemie międzynarodowym, możemy wyróżnić następujące części: 1) rozróżnialne elementy; 2) strukturę; 3) granicę; 4) wejścia; 5) wyjścia; 6) konwersję wewnątrzsystemową; 7) sprzężenie zwrotne. ${ }^{51}$

Elementy są najmniejszą częścią składową całości, stanowiącą system. W polskiej nauce o stosunkach międzynarodowych najczęściej przytaczany jest podział elementów, a równocześnie rodzajów systemów międzynarodowych, zaproponowany przez J. Kukułkę, który wyróżnił:

1) systemy uczestników stosunków międzynarodowych, składające się z uczestników, w tym głównie państw, ale naszym zdaniem, należy w coraz większym stopniu uwzględniać także aktorów pozapaństwowych;2) systemy stosunków międzynarodowych, w których elementami są stosunki lub oddziaływania uczestników; 3) systemy ról uczestników międzynarodowych, których elementami są role pełnione przez uczestników, pragnących na przykład odgrywać takie role jak: mocarstwowa, stabilizatora ładu międzynarodowego, obrońcy pokoju, lidera transformacji, wiernego sojusznika czy odbiorcy pomocy. ${ }^{52}$

Struktura systemu w najprostszym ujęciu stanowi zbiór relacji między jego elementami lub zespół sprzężeń między elementami a całością systemu. ${ }^{53}$ Struk-

${ }^{51}$ D. Easton, A System Analysis of the Political Life, Chicago-London 1979, s. 21-24; P. Sztompka, Analiza systemowa w naukach politycznych, [w:] Metodologiczne i teoretyczne problemy nauk politycznych, pod red. K. Opałka, Warszawa 1975, s. 87; P. J. Georgica, Główne zatożenia metodologiczne nauki o polityce, [w:] Nauka o polityce. Podręcznik akademicki, pod red. A. Bodnara, Warszawa 1988, s. 44; M. Chmaj, M. Żmigrodzki, Wprowadzenie do teorii polityki, Lublin 1996, s. 183; R. Zendrowski, Stosunki międzynarodowe. Vademecum, Wrocław 2006, s. 72; J. E. Dougherty, R. L. Pfaltzgraff, Jr., Contending, $2^{\text {nd }}$ edition, op. cit., s. 134-139; R. Gilpin, War, op. cit., s. 26-30; B.Krauz-Mozer, W. Szostak, Teoria, op. cit., s. 76; J. Kukułka, Problemy, op. cit., s. 162; Z. J. Pietraś, Podstawy, op. cit., s. 116.

${ }^{52}$ J. Kukułka, Teoria stosunków międzynarodowych, Warszawa 2000, s. 100.

${ }^{53}$ K. N. Waltz, The Anarchic Structure of World Politics, [w:] R. J. Art, R. Jervis, International Politics. Enduring Concepts and Contemporary Issues, New York 2007, s. 29; T. Łoś-Nowak, System międzynarodowy, [w:] Wspótczesne stosunki międzynarodowe, pod red. T. Łoś-Nowak, Wrocław 2008; s. 101; A. Rapoport, Zastosowanie izomorfizmu matematycznego w ogólnej teorii 
turę można także rozumieć jako wewnętrzną organizację systemu i dominujące w nim interakcje. Od usytuowania w strukturze systemu zależą więc rezultaty zachowań i oddziaływań elementów systemu. ${ }^{54}$ Określając to nieco inaczej, można stwierdzić, że to struktura systemu jest definiowana przez faktyczną wartość głównych parametrów systemu. ${ }^{55}$ Ważną rolę odgrywa tutaj percepcja systemu międzynarodowego, która jest funkcją pozycji zajmowanych przez uczestników międzynarodowych $\mathrm{w}$ danym systemie. ${ }^{56}$ Zasada organizująca strukturę międzynarodową ma charakter hierarchiczny w relacjach wewnętrznych bądź anarchiczny w stosunkach międzynarodowych. ${ }^{57}$

Zdaniem Z. J. Pietrasia, można wyróżnić pięć teoretycznych modeli struktury systemów międzynarodowych: 1) model formalny; 2) model zależności; 3) model kraty oddziaływań; 4) model pajęczyny współzależności; 5) model dynamiczny. ${ }^{58}$

Każdy system, jak z naciskiem podkreśla R. Gilpin, zasadniczo powinien posiadać granicę, aby można go było oddzielić od otaczającego środowiska oraz od innych systemów. ${ }^{59}$ Jednak jak zauważają inni autorzy, granica systemu jest swego rodzaju uproszczeniem i przenośnią, gdyż system nie zawsze może być wyodrębniony ze swojego otoczenia w sposób ostry i wyraźny. ${ }^{60}$

Możemy zatem przyjąć, że granice systemu chociaż niezbędne do celów analitycznych, mogą mieć charakter jedynie przybliżony i tymczasowy, czasami umowny i arbitralny, wynikający ze specyfiki identyfikowanych obiektów bądź zjawisk oraz intuicji, założeń, podejścia i poziomu analizy przyjętych przez badacza. Jest to szczególnie ważne w nauce o stosunkach międzynarodowych, gdyż granice systemów międzynarodowych są na ogół trudne do precyzyjnego wyznaczenia, a czasami są to jedynie granice umowne. ${ }^{61}$ Niemniej jednak, jak zgodnie zauważają K. N. Waltz i A. Wendt, koniecznym warunkiem zastosowania podejścia systemowego w stosunkach międzynarodowych jest oddzielenie analizy wewnętrznej na poziomie elementów od analizy na poziomie systemu, pomimo

systemów, [w:] Ogólna, op. cit., s. 54; W. Lamentowicz, Funkcje, op. cit., s. 89; M. Mazur, Cybernetyka, op. cit., s. 45.

${ }^{54}$ T. Łoś- Nowak, Stosunki, op. cit., s. 99.

${ }_{55}$ T. de Montrbrial, Działanie i system świata, przeł. A. Szeptycki, Warszawa 2011, s. 232.

${ }^{56} \mathrm{~B}$. Korany, Les modèles de politique étrangère et leur pertinence empirique pour les acteures du Tiers Monde: critique et contre-proposition, [w:] P. Braillard, Théories des relations internnational, Paris 1977, s. 16.

${ }^{57}$ J. Czaputowicz, Teorie stosunków międzynarodowych. Krytyka i systematyzacja, Warszawa 2008, s.179; K. N. Waltz, Theory, op. cit., s. 88-89.

${ }^{58}$ Z. J. Pietraś, Podstawy, op. cit., s. 118-119.

${ }^{59}$ R. Gilpin, War, op. cit., s. 26.

${ }^{60}$ G. M. Weinberg, Myślenie systemowe, tłum. Cz. Berman, R. Wielburski, Warszawa 1979, s. 152, 155; L. von Bertalanffy, Historia rozwoju i status ogólnej teorii systemów, [w:] Ogólna teoria systemów. Tendencje rozwojowe, pod red. G. J. Klira, thum. Cz. Berman, Warszawa 1976,, s. 43; B.Krauz-Mozer, W. Szostak, Teoria, op. cit., s. 77.

${ }^{61} \mathrm{~K}$. von Beyme, Wspótczesne teorie polityczne, przeł. J. Łoziński, Warszawa 2007, s. 180; P. Sztompka, Analiza, op. cit., s. 93. 
zachodzących procesów międzynarodowych współzależności i zacierania się granic między nimi. ${ }^{62}$

Jednym ze sposobów wyodrębnienia systemu jest założenie o możliwości sterowania systemem. Granice systemu obejmowałyby wtedy zbiór elementów podlegających kontroli decydenta lub określonej grupie decydentów. ${ }^{63}$ Nie możemy oczywiście przy tym zapominać, że w stosunkach międzynarodowych podejmowane decyzje są funkcją co najmniej dwóch formalnie suwerennych ośrodków decyzyjnych. ${ }^{64}$

Poza wyodrębnionym w ten sposób systemem międzynarodowym pozostaje otoczenie, które może być pojmowane na dwa sposoby. W pierwszym, szerokim ujęciu otoczeniem będzie całe uniwersum zjawisk i procesów przyrodniczych, klimatycznych i społecznych. Jednak ze względu na swoją nieokreśloność takie pojmowanie otoczenia jest mało przydatne do analizy stosunków międzynarodowych. W drugim, węższym ujęciu wydzielamy z otoczenia jedynie tę jego część, która pozostaje $\mathrm{w}$ istotnych relacjach przyczynowych $\mathrm{z}$ elementami systemu. Tę część określa się mianem środowiska systemu międzynarodowego ${ }^{65}$

Relacje między systemem a środowiskiem międzynarodowym możemy podzielić na trzy typowe przypadki:

1) środowisko jest przyjazne i mamy sytuację współdziałania z systemem;

2) środowisko jest neutralne i mamy sytuację sprzyjającą bądź obojętną;

3) środowisko jest nieprzyjazne i mamy sytuację zagrożenia.

Systemy działające w nieprzyjaznym otoczeniu można podzielić na sytuacje kryzysowe, w których poziom zagrożeń jest tak duży, że przekracza dopuszczalną wartość normalnego działania systemu i zakłóca jego funkcjonowanie oraz sytuację katastroficzną, podczas gdy destrukcyjne impulsy otoczenia przerastają możliwości adaptacyjne systemu i mogą prowadzić do jego destrukcji. ${ }^{66}$

Przez wejścia należy rozumieć określone oddziaływania środowiska na system. Różnorodność i liczba tych oddziaływań są olbrzymie. W związku z tym istnieje analityczna konieczność ograniczenia liczby zmiennych. Oddziaływania mogą być funkcjonalne, jeśli wzmacniają stabilność systemu lub dysfunkcjonalne, gdy destabilizują system międzynarodowy. ${ }^{67}$

${ }^{62}$ A. Wendt, Społeczna teoria stosunków międzynarodowych, przeł. W. Derczyński, Warszawa 2008, s. 21-22; K. N. Waltz, Theory, op. cit., s. 114-115.

${ }^{63}$ P. B. Checkland, Formułowanie problemu w analizie systemowej, [w:] Analiza systemowa, op. cit., s. 151.

${ }^{64}$ Z. J. Pietraś, Decydowanie, op. cit., s. 50.

${ }^{65}$ J. Kukułka, Problemy, op. cit., s. 165; Z. J. Pietraś, Podstawy, op. cit., s. 119; P. Sztompka, Analiza, op. cit., s. 94-95.

${ }^{66}$ P. Sienkiewicz, P. Górny, M. Pelc, Analiza systemowa sytuacji konfliktowych i kryzysowych, [w:] Badania operacyjne i systemowe a zagadnienia spoteczeństwa informacyjnego, bezpieczeństwa $i$ walki, red. J. Kacprzyk, A. Najgebauer, P. Sienkiewicz, Warszawa 2008, s. 249.

${ }^{67}$ J. Kukułka, Problemy, op. cit., s. 166; Z. J. Pietraś, Podstawy, op. cit., s. 119; P. Sztompka, Analiza, op. cit., s. 96-97. 
Wyjścia systemu międzynarodowego to oddziaływania systemu na środowisko. Można wyróżnić cztery rodzaje wyjść: 1) ekstrakcyjne, czyli konkretne decyzje szczegółowe; 2) regulacyjne, odnoszące się do wyznaczania norm postępowania; 3) dystrybucyjne, czyli dotyczące podziału dóbr lub wartości; 4) symboliczne, odnoszące się do wartości. ${ }^{68}$

Konwersja wewnątrzsystemowa to proces przetwarzania impulsów odbieranych przez wejścia systemu międzynarodowego i wysyłania ich przez wyjścia. Przekształcanie przez system międzynarodowy bodźców wchodzących w wychodzące wymaga dokładnego poznania wewnętrznych mechanizmów decyzyjnych danego systemu. ${ }^{69}$

Sprzężenie zwrotne to proces, który przebiega między wyjściami a wejściami systemu międzynarodowego i polega na przetwarzaniu przez środowisko międzynarodowe impulsów wysyłanych przez system. Podstawowym celem sprzężenia zwrotnego jest usuwanie odchyleń między aktualnym działaniem systemu a działaniem pożądanym lub zamierzonym. O skuteczności sprzężenia zwrotnego decydują następujące cztery czynniki: 1) zmienność środowiska międzynarodowego; 2) szybkość podjęcia reakcji systemu na zmiany; 3) stopień skuteczności działań korygujących; 4) zdolność przewidywania nowych sytuacji i umiejętność podejmowania działań wyprzedzających. ${ }^{70}$

Przyjmuje się, że funkcjonowanie systemu można wyjaśniać przez opis wewnętrzny lub zewnętrzny. Opis wewnętrzny sprowadza się do ujęcia strukturalnego, czyli opisu zachowania się systemu za pomocą zmiennych określających stany tego systemu i ich wzajemne zależności. Natomiast opis zewnętrzny jest wyjaśniany przez zachowania systemu w jego wzajemnych relacjach ze środowiskiem. ${ }^{71}$ Charakterystykę systemu bada się na ogół przez analizę zachowań typowych oraz przez zachowanie wyjątkowe. ${ }^{72}$

D. M. Mesarovic uważa ponadto, że działanie każdego systemu można starać się opisać albo przez sprzężenie między wejściem a wyjściem systemu, albo przez proces dążenia do osiągnięcia zamierzonego celu przez ten system. ${ }^{73}$

Celem każdego systemu jest jego przetrwanie. Trwałe istnienie systemu jest podstawowym warunkiem jego funkcjonowania, ale w sposób oczywisty wyznacza także możliwości podjęcia badań w tym zakresie. Istnienie w sensie najbardziej ogólnym oznacza zachowanie tożsamości systemu. ${ }^{74}$ Przetrwanie systemu zależy od jego zdolności adaptacyjnych, czyli możliwości dostosowania

${ }^{68}$ Z. J. Pietraś, Podstawy, op. cit., s. 119; P. Sztompka, Analiza, op. cit., s. 99.

${ }^{69}$ P. Sztompka, Analiza, op. cit., s. 100-102; Z. J. Pietraś, Podstawy, op. cit., s. 120.

70 Z. J. Pietraś, Podstawy, op. cit., s. 120. P. Sztompka, Analiza, op. cit., s. 102-103.

${ }^{71}$ L. von Bertalanffy, Historia rozwoju i status ogólnej teorii systemów, [w:] Ogólna teoria systemów. Tendencje rozwojowe, pod red. G. J. Klira, tłum. Cz. Berman, Warszawa 1976, s. 39-40.

${ }^{72}$ G. M. Weinberg, Myślenie, op. cit., s. 210.

73 D. M. Mesarovic, Matematyczna teoria systemów ogólnych, [w:] Ogólna, op. cit., s. 251.

${ }^{74}$ G. M. Wienberg, Ogólna teoria systemów w ujęciu informatyki, [w:] Ogólna, op. cit., s. 128,130 . 
jego funkcjonowania do zmian zachodzących w środowisku, oraz od sposobu przetwarzania informacji. Wyróżniamy tutaj dwie możliwości - zmiana struktury systemu lub jego części bądź zmiana modelu adaptacji. ${ }^{75}$

Koniecznym warunkiem zachowania ciągłości bytu systemu międzynarodowego jest istnienie homeostazy, łączącej funkcje konwersji i sprzężenia zwrotnego, polegającej na utrzymaniu dynamicznej równowagi funkcjonalnej systemu ze środowiskiem międzynarodowym. ${ }^{76} \mathrm{~W}$ innym ujęciu homeostazę można sprowadzić do procesu utrzymaniu takiego stanu systemu, w którym jego parametry będą miały wartości najkorzystniejsze z punktu widzenia możliwości sterowania tym systemem i najbardziej odległe od położenia skrajnego, mogącego spowodować jego zniszczenie. Wymaga to stworzenia homeostatu, czyli specjalnej części systemu odpowiedzialnego za utrzymanie równowagi funkcjonalnej..$^{77}$ Jak dotąd rolę podsystemu sterującego w systemie międzynarodowym odgrywały wielkie mocarstwa, które tworzyły różne konfiguracje w zależności od liczby głównych aktorów oraz podziału siły między nimi. ${ }^{78}$

Znajomość stanu systemu w przeszłości pozwala na określenie przewidywanych zachowań się systemu w teraźniejszości oraz w przyszłości. ${ }^{79}$ Jeżeli jednak nie znamy w miarę dokładnie stanu początkowego bądź nie potrafimy ocenić parametrów na wejściach i wyjściach, to nie jesteśmy także w stanie przewidzieć zachowania się systemu. Mamy wtedy do czynienia z systemem działającym $\mathrm{W}$ warunkach niepewności lub inaczej - z systemem stochastycznym. ${ }^{80}$

W ocenie kilku autorów, główną zaletą podejścia systemowego jest przekonanie, że pełną treść danego zdarzenia empirycznego możemy poznać dopiero w szerszym kontekście, ustalając charakterystykę jego relacji z innymi zdarzeniami. ${ }^{81}$

I chociaż, jak zauważają różni autorzy, system jest pojęciem abstrakcyjnym czy nawet metaforycznym, to naszym zdaniem, musi się także odnosić do określonej rzeczywistości międzynarodowej. ${ }^{82}$

${ }^{75}$ Ibid., s. 245-246 i 248.

${ }^{76}$ Z. J. Pietraś, Podstawy, op. cit., s. 121.

${ }^{77}$ M. Mazur, Cybernetyczna teoria układów samodzielnych, Warszawa 1966, s. 57.

${ }^{78}$ K. N. Waltz, International Structure, National Force, and the Balance of World Power, [w:] Political Power. A Reader in Theory and Research, ed. by R. Bell, D. V. Edwards, R. H. Wagner, New York 1969, s. 343; T. Łoś-Nowak, Stosunki, op. cit., s. 121; A. D. Rotfeld, Europejski, op. cit., s. 27; Z. J. Pietraś, Podstawy, op. cit., s. 117-118;

${ }^{79}$ K. N. Waltz, Theory, op. cit., s. 50.

${ }^{80}$ W. Findeisen, J. Gutenbaum, Modele, op. cit., s. 300-301.

${ }^{81}$ P. Sztompka, Teoria i wyjaśnienie. Z metodologicznych problemów socjologii, Warszawa 1973, s.117; T. Łoś-Nowak, Stosunki, op. cit., 52; J. Kukułka, Problemy, op. cit., s. 157.

${ }^{82}$ A. Bodnar, Historyczne, op. cit., s. 252; J. Kukułka, Problemy, op. cit., s. 167; T. Łoś-Nowak, Stosunki, op. cit., 95. 


\section{KATEGORIA SYSTEMU MIĘDZYNARODOWEGO W UJĘCIU GLÓWNYCH PARADYGMATÓW TEORII STOSUNKÓW MIĘDZYNARODOWYCH}

Należy przyjąć, że kategoria systemu międzynarodowego zajmuje kluczowe miejsce w nauce o stosunkach międzynarodowych. Jednak zarówno poszczególni autorzy, jak i rywalizujące ze sobą nurty badawcze nadają jej nieco odmienne znaczenie. Poniżej zostaną przedstawione wybrane kategorie systemu międzynarodowego reprezentatywnych przedstawicieli nurtu behawioralnego, neoliberalnego, neorealistycznego i konstruktywistycznego.

W ujęciu behawioralnym kategoria systemu międzynarodowego jest analizowana z punktu widzenia zmiennych, jak czyni to między innymi M. A. Kaplan, wyróżniając następujące ich rodzaje:

- podstawowe zasady systemu (essential rules of a system);

- zasady transformacji systemu (transformations rules of system);

- zmienne klasyfikacji uczestników (actor classificatory variables);

- zmienne możliwości (capability variables);

- zmienne informacji (information variables).

Wymienione zmienne pozwoliły temu autorowi na wyodrębnienie dwóch historycznych i ośmiu abstrakcyjnych modeli systemów międzynarodowych, dzięki którym można starać się określać optymalne zachowanie państw w danym systemie. ${ }^{83}$

Przedstawiciel nurtu neorealistycznego K. N. Waltz w zdecydowany sposób odrzucił dorobek behawiorystów, proponując własne rozwiązania. Podstawą jego teorii jest koncepcja struktury systemu międzynarodowego. Według niego, system składa się ze struktury i oddziaływających wzajemnie na siebie elementów. Struktura natomiast to komponent obejmujący cały system, pozwalający ujmować go jako całość. Definicja struktury, jego zdaniem, musi pomijać charakterystykę elementów, ich zachowania i wzajemne oddziaływania. Różne struktury mogą powodować takie same rezultaty, pomimo zróżnicowania elementów i interakcji. Struktura może determinować skutki niezależnie od zmian na poziomie elementów, zanikania niektórych z nich i wyłaniania się innych. ${ }^{84}$

K. N. Waltz definiuje struktury polityczne, posługując się trzema parametrami. Są to mianowicie ${ }^{85}$ :

1) zasady uporządkowania (ordering principles),

2) cechy elementów (the character of the units),

3) rozkład potencjału (the distribution of capabilities).

Koncepcja struktury pozwala na wskazanie oczekiwanych skutków organizacyjnych oraz sposobu, w jaki struktury i elementy wchodzą w interakcje i oddziaływają na siebie. W przekonaniu K. N. Waltza, rozważania o strukturze

\footnotetext{
${ }^{83}$ M. A. Kaplan, System and Process in International Politics, New York 1957, s. 9-12.

${ }^{84}$ K. N. Waltz, Theory, op. cit., s. 77-79.

${ }^{85}$ Ibid., s. $88-99$
} 
zgodnie z jego propozycją rozwiązują problem odróżniania zmian na poziomie elementów od zmian na poziomie systemu ${ }^{86}$

Systemem międzynarodowym, jak dowodzi K. N. Waltz, zarządzają wielkie mocarstwa. W jego ocenie, model bipolarny jest bardziej optymalnym rozwiązaniem niż multipolarny, zapewniając większą stabilność systemu i większą przewidywalność zachowań dwóch głównych graczy. ${ }^{87}$

Przedstawiciele nurtu neoliberalnego R. O. Keohane i J. S. Nye, Jr. dokonali analizy stosunków międzynarodowych z poziomu systemu, wskazując na pogłębianie się zjawisk i procesów, które określili mianem złożonej współzależności (complex interdependence). Ich zdaniem, opis i analiza systemów międzynarodowych w większym stopniu niż wcześniej musi uwzględniać oprócz państw, także aktywność innych uczestników stosunków międzynarodowych, takich jak organizacje międzynarodowe i korporacje transnarodowe, oraz wyjść poza tradycyjny obszar badawczy, jaki stanowią kwestie bezpieczeństwa i konfliktu interesów, poszerzając pole analityczne o zagadnienia ekonomiczne i społeczne. Głównymi przejawami złożonej współzależności zmian zachodzących w systemie międzynarodowym są następujące właściwości ${ }^{88}$ :

1) rosnąca rola uczestników transnarodowych;

2) zwiększająca się ilość oraz intensywność formalnych i nieformalnych więzi i interakcji między uczestnikami stosunków międzynarodowych;

3) pogłębiająca się wieloaspektowość i słabnąca hierarchiczność relacji między tymi uczestnikami;

4) spadek znaczenia siły militarnej na rzecz instrumentów ekonomicznych i instytucjonalnych.

Reprezentant nurtu konstruktywistycznego A. Wendt utrzymuje, że struktura każdego systemu społecznego, w tym również systemu międzynarodowego, składa się z trzech elementów: 1) intersubiektywnej wiedzy, idei, rozumienia i oczekiwań; 2) środków materialnych, które są wzmacniane przez wiedzę; 3) interesów przyjmujących formę regularnych praktyk i tworzących wzorce przewidywalnych zachowań. ${ }^{89}$

Przy czym, jak podkreśla A. Wendt, podstawowe założenia konstruktywizmu opierają się na dwóch podstawowych zasadach: 1) struktury relacji społecznych są zdeterminowane przez podzielane wspólne idee, a nie przez warunki materialne

${ }^{86}$ Ibid., s. $100-101$.

${ }^{87}$ K. N. Waltz, Theory, op. cit., s. 193.

${ }^{88}$ R. O. Keohane i J. S. Nye, jr., Power and Interdepedence: World Politics in Transition, Boston 1977, s. 19-26; E. Dougherty, R. L. Pfaltzgraff, Jr., Contending, op. cit., $4^{\text {th }}$ edition, s. 102-103; R. Jackson, G. Sørensen, Wprowadzenie, op. cit., s. 121-122; R. Tenerowicz, System, op. cit., s. 41-42.

${ }^{89}$ A. Wendt, Spoleczna, op. cit., s. 134; J. Czaputowicz, Teorie, op. cit., s. 311; R Jackson, G. Sørensen, Wprowadzenie, op. cit., s. 271. 
oraz 2) tożsamości i interesy aktorów stosunków międzynarodowych są wytworem wspólnych idei, a posiadane są z natury. ${ }^{90}$

Zdaniem tego autora, system międzynarodowy należy analizować na dwóch poziomach - makrostruktury i mikrostruktury. W obu przypadkach należy rozpatrywać zachowania oraz właściwości z punktu widzenia wpływów przyczynowych oraz stanowiących. ${ }^{91}$

$\mathrm{Z}$ przedstawionych koncepcji wynika, że kategoria systemu międzynarodowego stanowi jedynie punkt wyjścia różnorodnych i bardzo często skrajnie odmiennych oraz wzajemnie wykluczających się teorii. Pomimo tych niedogodności, jak stwierdzają B. Buzan i R. Little, podejście systemowe ma tę przewagę nad innymi, że pozwala spośród miriad wydarzeń zachodzących na świecie wyselekcjonować te najważniejsze, ujawniając pewne schematy i prawidłowości działania w plątaninie faktów w tej niezwykle skomplikowanej maszynerii, jaką niewątpliwie są stosunki międzynarodowe. ${ }^{92}$

Zastosowanie podejścia systemowego do eksplanacji stosunków międzynarodowych musi jednak, zdaniem części autorów, uwzględniać trzy podstawowe wymogi. Pierwszym jest konieczność przyjęcia założenia dotyczącego specyfiki środowiska międzynarodowego, a mianowicie jego policentryczności, anarchiczności, złożoności i żywiołowości. Dwa kolejne wymogi dotyczą paradoksu całościowości i hierarchiczności. Paradoks pierwszy polega na tym, że nie jest możliwe sprowadzenie cech systemu do sumy cech jego elementów oraz wyprowadzenie cech całości z cech tych elementów. Paradoks hierarchiczności polega natomiast na relatywnym postrzeganiu samego pojęcia system, który może być jednocześnie elementem lub podsystemem w innym systemie bądź nadsystemem, W zależności od węższego lub szerszego ujęcia. ${ }^{93}$

\section{KLASYFIKACJE}

Jak zauważa T. Łoś-Nowak, klasyfikacja systemów międzynarodowych jest zawsze bardzo trudnym i złożonym przedsięwzięciem metodologicznym. Najogólniej rzecz ujmując, zastosowane przez poszczególnych autorów kryteria podziału, niezależnie od ich indywidualnych preferencji, są wyodrębniane na podstawie następujących przesłanek: $:^{94}$

- skali spójności elementów systemu bądź stopnia ich podobieństwa i komplementarności,

- charakteru powiązań wzajemnych,

\footnotetext{
${ }^{90}$ A. Wendt, Spoleczna, op. cit., s. 11.

${ }^{91}$ Ibid., s. 138-149.

${ }^{92}$ B. Buzan, R. Little, Systemy, op. cit., s. 53.

${ }^{93}$ J. Kukułka, Problemy, op. cit., s. 168; T. Łoś-Nowak, System, op. cit., s. 103; K. N. Waltz, Theory, op. cit., s. 88.

${ }^{94}$ T. Łoś-Nowak, Stosunki, op. cit., s. 119
} 
- układu sił w systemie,

- struktury relacji w systemie.

Poniżej zostaną przedstawione przykłady klasyfikacji systemów międzynarodowych, reprezentujące subiektywne stanowiska różnych autorów.

J. D. Singer i M. Small wyróżniają trzy rodzaje systemów w stosunkach międzynarodowych ${ }^{95}$ :

1) system globalny (global system), obejmujący różne kategorie uczestników międzynarodowych reprezentujących wszystkich mieszkańców Ziemi;

2) system międzynarodowy (international system), w którego skład wchodzą państwa, narody i organizacje międzynarodowe;

3) system międzypaństwowy (interstate system), tworzony wyłącznie przez państwa.

W ramach tego ostatniego autorzy wyodrębniają dodatkowe dwa typy: 1) system centralny (central system), tworzony przez grupę państw, które ze względu na istniejące między nimi powiązania, posiadany potencjał i osiągnięty poziom rozwoju wspólnie odgrywają kluczową rolę w stosunkach międzynarodowych;2) system wielkich mocarstw (major power system), obejmujący relacje współpracy i rywalizacji największych potęg. ${ }^{96}$

Zbliżoną klasyfikację systemów zaproponował O. R. Young. Jego zdaniem, system składający się ze wszystkich uczestników międzynarodowych należy określać jako system światowy (world system), natomiast system obejmujący tylko państwa, to system międzynarodowy (international system), będący podsystemem systemu światowego. ${ }^{97}$

R. Aron wyróżnia dwa główne międzynarodowe systemy państw - system homogeniczny lub system heterogeniczny. W każdym z nich może wystąpić dwubiegunowy lub wielobiegunowy model równowagi sił. ${ }^{98}$

F. H. Hartmann wyodrębnia pięć potencjalnych modeli systemów międzynarodowych 1) system unilateralny, 2) system równowagi sił, 3) system bezpieczeństwa zbiorowego, 4) rząd światowy, 5) system światowego podboju. ${ }^{99}$

K. J. Holsti wymienia pięć podstawowych rodzajów systemów międzynarodowych: 1) hierarchiczny, 2) rozproszony, 3) rozproszonych bloków, 4) spolaryzowany (polar), 5) wielobiegunowy. ${ }^{100}$

E. A. Kołodziej, analizując problem bezpieczeństwa międzynarodowego po zimnej wojnie, podaje sześć systemów międzynarodowych, które uszeregowal hierarchicznie. Są to mianowicie 1) wspólnota bezpieczeństwa, 2) hegemoniczne

${ }^{95}$ J. D. Singer, M. Small, The Wages of War 1816-1968. A Statistical Handbook, New York 1972, s. 16-19.

${ }^{96}$ Ibid., s. $18-19$.

${ }^{97}$ O. R. Young, The Actors in World Politics, [w:] The Analysis of International Politics, eds.J. N. Rosenau, V. Davis, M. A. East, New York 1972, s. 140.

${ }_{98}^{8}$ R. Aron, Paix et Guerre entre les nations, Paris 1962, s. 106-113, 137-156.

${ }^{99}$ F. H. Hartmann, The Relations of Nations, New York 1962, s. 301.

${ }^{100}$ K. J. Holsti, International Politics. A Framework for Analysis, London 1976. 
przywództwo oparte na porozumieniu, 3) pluralistyczna wspólnota bezpieczeństwa; 4) koncert mocarstw, 5) strefy wpływów oparte na przymusie hegemonicznego przywódcy, 6) równowaga sił. ${ }^{101}$ :

M. A. Kaplan jest autorem najbardziej znanej i rozbudowywanej klasyfikacji systemów międzynarodowych. Wyróżnia on sześć podstawowych modeli: ${ }^{102}$

1) system równowagi sił,

2) luźny system bipolarny,

3) ścisły system bipolarny,

4) system uniwersalny,

5) system hierarchiczny,

6) system jednostronnego weta.

Oprócz wyżej wymienionych, w późniejszym czasie ten sam autor dodał jeszcze cztery modele mieszane ${ }^{103}$ :

7) bardzo luźny system bipolarny,

8) system odprężenia,

9) system niestabilnych bloków,

10) system niepełnej proliferacji nuklearnej.

Jeden z autorów, zainspirowany dorobkiem M. A. Kaplana, a jednocześnie krytycznie odnoszący się do pewnej części jego koncepcji, proponuje własną klasyfikację systemów międzynarodowych, za podstawę ich wyodrębnienia przyjmując rzeczywisty udział wielkich mocarstw w tworzeniu danego modelu. Są to: system unipolarny, system bipolarny, system multipolarny i system uniwersalny. ${ }^{104}$

I. Wallerstein w swojej koncepcji system-świat wyróżnia trzy rodzaje podsystemów międzynarodowych: centrum, semiperyferie i peryferie. Według tego kryterium, następuje hierarchizacja państw w systemie międzynarodowym. Główną rolę odgrywa centrum, grupujące najsilniejsze i najbogatsze państwa, ustalające reguły funkcjonowania systemu i czerpiące $\mathrm{z}$ tego tytułu określone korzyści. Na przeciwległym biegunie są państwa peryferyjne: słabe, zapóźnione, biedne i tylko częściowo samodzielne, stanowiące przedmiot stałej penetracji ekonomicznej i politycznej. Między centrum a peryferiami znajdują się semi-peryferia, będące pod nieustanną presją państw centrum oraz starające się wywierać wpływ na państwa peryferyjne, gdyż ich stałą troską jest niedopuszczenie do utraty dotychczasowego statusu i stoczenie się na pozycje peryferii. Ruch państw w systemie między poziomami hierarchii jest co prawda dopuszczalny zarówno w dół jak i w górę, ale jest utrudniony przez sztywne podziały i możliwy tylko

${ }^{101}$ E. A. Kołodziej, Bezpieczeństwo międzynarodowe po zimnej: od globalizacji do regionalizacji, [w:] Bezpieczeństwo narodowe i międzynarodowe u schytku XX wieku, red. D. Bobrow, E. Haliżak, R. Zięba, Warszawa 1997, s. 59-60.

102 M. A. Kaplan, System, op. cit., s. 21-53.

${ }_{103}$ M. A. Kaplan, Towards Profesionalism in International Theory, New York-London 1979, s. $147-153$.

${ }^{104}$ D. Kondrakiewicz, Systemy równowagi sit w stosunkach międzynarodowych, Lublin 1999, s. 44 . 
z uwzględnieniem poziomu pośredniego. Nie można bowiem awansować z peryferii bezpośrednio do centrum i odwrotnie - zostać zdegradowanym z centrum do peryferii. $\mathrm{W}$ obu przypadkach po drodze znajdują się semiperyferia, pełniące rolę łącznika i amortyzatora napięć między centrum a peryferiami. ${ }^{105}$

B. Buzan i R. Little, koncentrując się na kwestii ewolucji systemów międzynarodowych w historii świata, wyróżniają trzy główne typy systemów ${ }^{106}$ :

1) systemy przedmiędzynarodowe - sprowadzające się do podstawowych interakcji o charakterze społeczno-kulturalnym, mogące zawierać też elementy handlu niekomercyjnego, ten rodzaj systemu występował masowo w społecznościach niezurbanizowanych;

2) międzynarodowe systemy gospodarcze - obejmujące rozwinięte relacje gospodarcze oraz społeczno-kulturowe, ale pozbawione wymiaru polityczno-militarnego;

3) pełne systemy międzynarodowe - zawierające wszystkie wymiary interakcji, chociaż możliwe są warianty ograniczone tylko do kontaktów polityczno-militarnych bez wymiany gospodarczej.

Część autorów, za punkt odniesienia przyjmując podpisanie traktatów westfalskich jako czynnik konstytuujący nowoczesny system międzynarodowy w Europie, dzieli historię stosunków międzynarodowych na okres przedwestfalski, westfalski i powestfalski. Takie ujęcie występuje w różnych konfiguracjach. M. Pietraś wyróżnia etap przedwestfalski, westfalski i późnowestfalski. ${ }^{107}$ G. Sorensen, opisując zmiany funkcji państwa w stosunkach międzynarodowych, wyodrębnia system przedwspółczesny, westfalski i powspółczesny. ${ }^{108}$

R. Cooper stwierdza, że w obecnym stanie rzeczy stosunki międzynarodowe nie tworzą już pojedynczego systemu politycznego, lecz składają się z trzech odrębnych systemów: przednowoczesnego, nowoczesnego i ponowoczesnego. ${ }^{109}$

Należy podkreślić, że w naukach społecznych pojęcia przednowoczesności, nowoczesności i ponowoczesności są szeroko wykorzystywane. Jednak posługiwanie się tymi kategoriami do analizy konkretnych zjawisk i procesów międzynarodowych, jak zauważa J. Goody, nie zawsze jest adekwatne, ponieważ są to pojęcia relatywne, a sama nowoczesność podlega ciągłym zmianom i nie poddaje się precyzyjnej periodyzacji. ${ }^{110}$

${ }^{105}$ I. Wallerstein, Analiza, op. cit., s. 47-49.

${ }^{106}$ B. Buzan, R. Little, Systemy, op. cit., s. 132.

${ }^{107}$ M. Pietraś, Istota i ewolucja międzynarodowych stosunków politycznych, [w:] Międzynarodowe stosunki polityczne, red. M. Pietraś, Lublin 2006, s. 17.

${ }^{108}$ T. Łoś-Nowak, Stosunki, op. cit., s. 174-175.

${ }_{109}$ R. Cooper, Pękanie grani. Porządek i chaos w XXI wieku, przeł. P. Kłosowicz,Poznań 2005 , s. 37-56.

110 J. Goody, Kapitalizm i nowoczesność. Islam, Chiny, Indie a narodziny Zachodu, przekł. i wstęp M. Turowski, Warszawa 2006, s. 42. 


\section{PODSUMOWANIE}

System międzynarodowego wciąż pozostaje kluczową kategorią w nauce o stosunkach międzynarodowych, pomimo tego, że poszczególni autorzy i konkurujące nurty badawcze nie są zgodni odnośnie definicji, najważniejszych cech, podstawowych zasad, głównych elementów i struktury systemu międzynarodowego. ${ }^{111}$

Zastosowanie podejścia systemowego jest bardzo przydatne w warunkach względnej stabilności i przewidywalności działania systemu, kiedy przynajmniej hipotetycznie możemy stworzyć listę ewentualnych zachowań systemu oraz określić przybliżoną szansę ich realizacji. Natomiast w sytuacji szybko, lawinowo i nieustannie zachodzących zmian o trudnych do przewidzenia konsekwencjach dla funkcjonowania systemu efektywność podejścia systemowego jest relatywnie dużo mniejsza. ${ }^{112}$

Jak podkreślają B. Krauz-Mozer i W. Szostak, słabością podejścia systemowego w nauce o stosunkach międzynarodowych jest ograniczona możliwość całościowego wyjaśniania i przewidywania zmian, jakie zachodzą pomiędzy środowiskiem, podsystemami a elementami systemu. Teorie systemowe są bardzo przydatne do opisu i eksplantacji procesów funkcjonowania systemów międzynarodowych, w tym także destrukcji systemu, biorąc pod uwagę przekroczenie wielkości granicznych na wejściach, wyjściach lub innych częściach podsystemów. Brak jest natomiast ogólnej teorii wyjaśniającej prawidłowości samoistnego tworzenia się nowych systemów, powstałych w wyniku syntezy podsystemów i elementów pozostałych z rozpadu starego systemu. ${ }^{113}$

Znane i powszechnie przyjęte $\mathrm{w}$ stosunkach międzynarodowych teorie adaptacji i modele równowagi sił, opierające się na przekonaniu o istnieniu jakiejś formy homeostazy, okazują się daleko niewystarczające do eksplikacji gwałtownych zmian, rewolucji, narastania napięć, kryzysów czy powstawania stanów nieprawdopodobnych. Zdawał sobie z tego sprawę już Cannon, który podkreślał, że obok homeostazy istnieje także heterostaza, określająca te zjawiska. ${ }^{114}$

Przychylamy się do opinii tych autorów, którzy uważają, że obecny system międzynarodowy tak dalece odbiega od stanu równowagi, że nie jest w stanie długo i sprawnie funkcjonować na dotychczasowych warunkach, nieuchronnie zbliżając się do punktu bifurkacji, w którym być może będzie musiał ulec przekształceniu bądź zostanie zastąpiony przez inny system. ${ }^{115}$ Jak wskazują różni autorzy, poważne zakłócenie równowagi w systemie międzynarodowym może

${ }^{111}$ R. Tenerowicz, System, op. cit., s. 51.

112 W. Pogorzelski, Teoria systemów i metody optymalizacji, Warszawa 1996, s. 64, A. Bard, J. Söderqvist., Netokracja, op. cit., s. 152.

${ }_{113}$ B. Krauz-Mozer, W. Szostak, Teoria, op. cit., s. 77.

${ }^{114}$ L. von Bertalanffy, Ogólna, op. cit., 53.

115 I. Wallerstein, Utopistka Alternatywy historyczne dla XXI wieku, thum. I. Czyż, Poznań 2008, s. 39. 
prowadzić do rozpadu systemu i chaosu lub do wyłonienia się jakiejś nowej formy uporządkowanego układu. ${ }^{116}$

Zastosowanie podejścia systemowego jest możliwe pod warunkiem, że świat nie jest chaotyczny i nadmiernie skomplikowany, aby zastosować kategorie analizy systemowej. ${ }^{117} \mathrm{~W}$ takim bowiem przypadku mamy do czynienia ze zjawiskami określanymi jako nieliniowe systemy dynamiczne, w których wzajemnie splatają się ze sobą determinizm i losowość, konieczność i przypadek. ${ }^{118}$

Znaczne nadzieje w tej mierze wiązano z rozwojem teorii chaosu, jednak możliwość jej praktycznego wykorzystania w nauce o stosunkach międzynarodowych okazała się na obecnym etapie jej rozwoju zdecydowanie niewystarczająca wobec oczekiwań w tym zakresie. Teoria chaosu wciąż jest bardziej metaforą niż narzędziem badawczym dostosowanym do specyfiki stosunków międzynarodowych. ${ }^{119}$

\title{
INTERNATIONAL SYSTEM AS THE CATEGORY IN THE SCIENCE OF INTERNATIONAL RELATIONS
}

\begin{abstract}
The main aim of the article it to analize the category of international system in the science of international relations. The author discuss conception of system, definitions of the international system, their main parts, the classification international systems and category of international systems on the difference approaches theory of the international relations: behavioral, realism, liberal and constructivist. The author conclude that international system still being the key category in the science of international relations.
\end{abstract}

Key words: international system, international relations, theory of the international relations

${ }^{116}$ A. Z. Kamiński, Lad światowy: anatomia zagrożeń (perspektywa Europy Środkowej), „Sprawy Miedzynarodowe” 2007, nr 1, s. 5; I. Wallerstein, Utopistyka, op. cit., s. 39.

${ }^{117}$ L. von Bertalanffy, Ogólna, op. cit., s. 115.

118 P. Sienkiewicz, P. Górny, M. Pelc, Analiza, op. cit., s. 251.

${ }^{119}$ M. Angel, J. P. Plaza i Font, The Idea of Chaotic System as a Metaphor for the International Arena, IV Convention - Central and East European International Studies Association (CEEISA), University of Tartu, 25-26 June, 2006, www.ceeisaconf.ut.ee/orb.aw/class; P. Frankowski, Świat pozimnowojenny w świetle teorii chaosu, [w:] Porządek międzynarodowy u progu XXI wieku, pod. red. R. Kuźniara, Warszawa 2005, s. 546; J. E. Dougherty, R. L. Pfaltzgraff, Jr, Contending, op. cit., $4^{\text {th }}$ ed., s. 569 . 